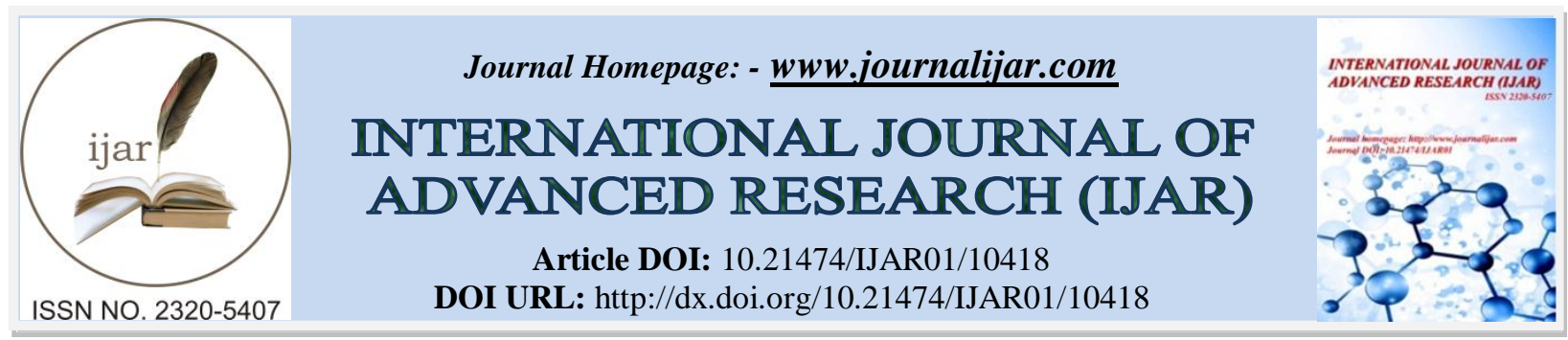

RESEARCH ARTICLE

\title{
DESTINATION BRAND IMAGE EVALUATION : A CASE STUDY OF MAHARASHTRA TOURISM
}

Ms. Pallavi Kamble and Dr. Madhuri Sawant

Department of Tourism Administration, Dr Babasaheb Ambedkar Mrathwada University, Aurangabad (MS), India 431004.

\section{Manuscript Info}

Manuscript History

Received: 30 November 2019

Final Accepted: 31 December 2019

Published: January 2020

Key words:-

Destination Brand Image, Experiences,

Expectations, Domestic Tourists,

Foreign Tourists, Maharashtra Tourism

\begin{abstract}
Global competition in tourism has led the DMO's to develop various strategies for marketing. This paper focuses on the branding image of state of India i.e. Maharashtra. Therefore there is need by the DMO's to take strong and positive steps for the marketing of Maharashtra tourism for altering its existing image. This research aims to evaluate the gap between experience and expectations of domestic and foreign tourists about the brand image of Maharashtra tourism. For this study data was collected from 435 domestic and 663 foreign tourists at the sample destinations by using purposive sampling. Data was analyzed by using paired t-test. The results indicate that there is a need of improvement in accessibility for domestic tourist which is core need for infrastructure development. It has suggested that for increasing the average length of stay of foreign tourist in state of Maharashtra range of tourism products can be promoted including culture, wildlife, cuisine, adventure sports etc.
\end{abstract}

Copy Right, IJAR, 2020,. All rights reserved.

\section{Introduction:-}

According to report of (World Travel \& Tourism Council, 2019), Travel \& Tourism is an significant commercial activity in most countries of the globe. The direct contribution of this industry to GDP in 2018 was USD2, 750.7 billion which comes to $3.2 \%$ of world GDP. Travel \& Tourism generated 122,891,000 jobs directly in 2018 it comes $3.8 \%$ of total employment of the globe. To tap this huge economic potential many Destination Marketing organizations (DMOs) are competing with each other to attract a greater number of domestic and foreign tourists. It has observed by (Li \& Vogelsong, 2002)that, tourists are enjoying variety of destinations but the DMOs are finding it difficult to differentiate their attractions from domestic or foreign competitors. Therefore, creating a distinctiveness or image has become the major challenge for the tourism industry professionals and destination marketers.

(Kim \& Yoon, 2003) has noted that, destination image plays a vital role in attracting potential tourist to the destination. So, it is need of the hour to understand the destination image for framing the suitable marketing strategies based on tourists' expectations and experiences aimed at catering the competitive destinations' products to current and potential tourists.(Fakeye and Crompton, 1991; Gunn, 1972), states that, there are three types of images that individuals hold for a destination i.e. organic image, induced image, and complex image. These three types of images are based on individual experience with a particular destination. An organic image arises from non-tourism information such as newspaper reports, geography books, television reports, magazine articles. An induced image can arise from tourism-specific information such as a destination brochure or vacation web site, which is a product 
of destination marketing efforts. The major difference between organic image and induced image lies in individual's intention or motivation of travel. When tourist visits to the selected destinations, they develop a complex image which is an outcome of actual interaction with the area, as cited by (Hanzaee \& Saeedi, 2011).

\section{Review of Literature:- Destination Image:}

(Hunter, 2012) has identified Seoul's projected destination image by using visual method for analyzing photos printed in tourism brochures and guidebooks. It was suggested that, destination image has to be designed by considering the actual needs and experiences of inhabitants and tourists. This research has recommended the three indicators for Brand Image measurement first the importance observed by the visitors related to uniqueness of attraction. Second is about the global destination image value (value anticipated before the travel and value observed while travelling) and the last is about the destination image ratio (DIR), calculated as ratio between the expected image and perceived image. Based on the second indicator (Xesfingi, Papadopoulou, Karamanis, \& Martens, 2018) have evaluated the satisfaction level of tourists visited Dubai and measured the intention to visit Dubai based on the pre-trip destination image of potential tourists. It has found that, tourist satisfaction is based on various factors like economic, social and environmental which affect revisit intensions of visitors. The destination image is essential element which impacts the willingness of the individual to visit the attraction and the satisfaction level after visit. Destination image could be used by DMO as a structure for the framing of marketing campaigns which will help in word of mouth references of tourism stakeholders.

A study by (Qu, Hyunjung, \& Hyunjung, 2011) has examined the relationships among brand associations (i.e., cognitive, affective, and unique image components), brand image (i.e., overall image of a destination), and tourists' future behaviors. Results of the study show that, successful destination branding is necessary to overcome its lack of clear destination image. Destination image plays a facilitating role between the three image components as the brand associations and the behavioral intentions. Strong and distinctive destination image should not only be a goal of branding practices in capturing consumers' minds but also as a mediator to influence consumer behaviors, directly related to the success of the tourist destinations. Similarly (Piva, Cerutti, Prats, \& Raj, 2017) have examined how visitors evaluate the impact of cultural events and festivals in improving the image of a tourist destination with the help of the Stresa Festival (Stresa, Lake Maggiore, Italy) as a case study. It was concluded that, cultural events have become an important part of destination image and branding processes.

\section{Destination Brand:}

(Ekinci, 2003) has explained that, destination branding is the second stage of building favorable destination image. The process of destination branding begins when the evaluation of destination image includes a strong emotional attachment. Successful destination branding involves establishing a mutual relationship between destinations and tourists emotional and basic needs.(Ashton, 2014) has examined the concept of tourist destination brand image progress centered on a case study of Southland province of New Zealand. It has found that, the first component of brand image is based on the attribute holistic, including the overall tourist infrastructure. Second, provide a clear image and picture of the destination attributes that can be created in tourist's mind; last to seek or create the uniqueness, which is based on creating the actual involvement at the destination is considered as one of the explicit characteristics of a strong brand image in developing tourist destination branding.

(Verissimo, Tiago, Tiago, \& Jardim, 2017) have studied the destination brand image of small island of Madeira which is an autonomous region of Portugal. It is an archipelago comprising 4 islands off the northwest coast of Africa. The findings recommended that Destination Marketing Organisations (DMOs) should promote reliable and combined strategies which should increase awareness in initial phases. DMOs should inspect the resources, determine the wants of the target markets and then formulate marketing strategies so that destination should be noticeable during the selection process. They must confirm that customer experience should match with the expectations, which would help in enhancing brand loyalty. Likewise (Naidoo, Ramseook-munhurrun, \& Durbarry, 2010) have explored the brand image of Mauritius among European visitors. Findings of the study shows that the brand image of Mauritius is related with the three ' $S$ ' that is Sun, Sea and Sand, a serene and comforting environment, and the warmth of Mauritians. It has suggested that, in order to integrate the brand image of Mauritius, weak brand image features need to be rectified.

(Meža \& Seric, 2014) have studied the gap between perceptions and actual experience of tourist regarding branding and positioning of Croatia. This research has demonstrated that an innovative approach to destination branding by 
using the buyer authority and their inquisitiveness. It has suggested to, project the image based on the buyers' desires and need. Whatever the brand image of the destination present, it should be developed gradually keeping in mind the demands of the tourist. (D'Silva \& D'Silva, 2008) have detected the features which are considered as important by the foreign tourists while selecting India as a tourist destination. Findings suggests that, significant aspects for selecting India as an important holiday destination are Outdoor Activities, Natural Beauty, Culture and Tradition, Diversity in culture, Historic Sites, Places of worship, Beautiful cities and places and Rural life. It has also suggested that there is a need of influential, well-administered Nation Brand in coming days.

After review of literature it has found that many researchers have researched on destination image and tourist perceptions but limited studies are there related to brand image perception and brand image measurement. (Maumbe, 2015)

\section{Maharashtra Brand Image:}

Maharashtra is a unique state in India which offers several types of attractions for tourists. It has 6 world heritage sites including Ajanta, Ellora, Chatrapati Shivaji Maharaj Terminus, Elephanta Caves, Wesren Ghat (Kaas Plataeu) and Victorian Gothic and Art Deco Ensembles of Mumbai. It has 720 kilometers long seaside besides evergreen Konkan region. The Western Ghats and the Sahyadri mountain range provide hill stations and many hill forts and the Vidarbha region offers several wildlife sanctuaries and nature parks. It has more than 350 forts and 900 caves.(Department of Tourism \& Culture Affairs Government of Maharashtra, 2016)

(Varghese, 2002) has reported that, Maharashtra Tourism Development Corporation (MTDC) has started 'Unlimited Maharashtra' brand campaign in the year 2002. This campaign was aimed to focus the diverse nature of tourism products which Maharashtra has to offer to the tourists. MTDC started organizing road shows in foreign countries to attract Non- Resident Indians (NRI) and participating in tourism marts along with the private sector. It has also started 'Deccan Odyssey' a luxury train for the premium tourists on the lines of 'Palace on Wheel'. (Vora, 2012) has informed that, MTDC has launched 'Maharashtra Unlimited' quarterly magazine in 2012 which was concentrated on must-visit and unknown attractions, cultural and natural history, literature and eminent personalities of the Maharashtra State. In an article ("We are Progresssively Becoming an Ideal Tourist Destination," 2016) in business magazine Joint Managing Director of MTDC has revealed that, they were planning to sign an agreement with five bordering states that is Madhya Pradesh, Karnataka, Gujarat, Telengana and Goa for collaborative tourism promotion and have plan to sign agreement with Telangana to promote Buddhist tourism. Marketing and promotion of tourist attractions were precisely planned with the help of combination of marketing and promotional tools like road shows, participation in international and national exhibitions, active publicity campaign, use of information technology, cultural events, FAM tours and enhancing brand equity of the state by theme-based tourism products.

According to the report of (Maharashtra Tourism Development Corporation, 2015) most visited attraction of Maharashtra state are Ellora, Shirdi, Gateway of India, Tuljadevi, Dharshiv Caves Balaghat Mountains, Shanisinganapur, Juhu Chowpaty, Ajanta, Dualtabad Fort, Mahalaxmi Temple. Survey also studied the satisfaction level of domestic and foreign overnight visitors to Maharashtra. Findings suggested that, most of the domestic and foreign visitors were satisfied by the services including availability of Tour Operators, transport, and tourist guides, quality of accommodation, information centers, behavior of local people, maintenance of tourist attractions and quality of information. Most of the domestic (89.4\%), and foreign (92.6\%) overnight visitors opted the option 'As per expectation' for expectation level. This study gives an idea about the destination image perceived by domestic and foreign visitors. It indicates that destination Maharashtra is perceived as cultural and religious attraction.

\section{Re-branding of Maharashtra Tourism:}

In order to attract more tourists MTDC also launched some tourism products which are based on the idea of experiential tourism which will give tourist an opportunity to discover the lifestyle of local people, their customs and traditions. It includes Agri-tourism, village tourism, food tourism, educational tours, nature tours, social tourism, fishing, safaris, Tribal lifestyles, arts, handicrafts. MTDC has launched the scheme of 'Mahabhraman'to bring these various projects under one umbrella.(Maharashtra Tourism Development Corporation, n.d.-a)

Recently MTDC has also launched the 'Vari-Festival' to promote the spiritual tourism in state. Vari is 700-year-old tradition of Varkaris or dovotees of Vitthala deity travelling to Pandharpur a religious place by walk for 15 to 20 days to take a bow at Vitthala Temple. 
Need of assessment of Maharashtra Brand Image:

Table 1:- Foreign and Domestic Tourist Arrivals to Maharashtra (2001 to 2017).

\begin{tabular}{|l|l|l|l|l|l|l|}
\hline Year & Domestic Visitors & Foreign Visitors & Rank Domestic & Rank Foreign & $\begin{array}{l}\text { Percent share } \\
\text { Domestic }\end{array}$ & $\begin{array}{l}\text { Percent share } \\
\text { Foreign }\end{array}$ \\
\hline 2001 & 8479695 & 915399 & 6 & 1 & 3.58 & 16.83 \\
\hline 2002 & 9802527 & 768936 & 5 & 2 & 3.63 & 14.90 \\
\hline 2003 & 11272906 & 986544 & 6 & 1 & 3.6 & 14.7 \\
\hline 2004 & 13392212 & 1218382 & 6 & 1 & 3.7 & 14.7 \\
\hline 2005 & $1,43,29667$ & 1,449875 & 6 & 1 & 3.7 & 14.6 \\
\hline 2006 & 16880348 & 1712302 & 6 & 2 & 3.66 & 14.57 \\
\hline 2007 & 19226716 & 1928052 & 7 & 2 & 3.6 & 14.6 \\
\hline 2008 & 20553360 & 2056913 & 6 & 2 & 3.7 & 14.6 \\
\hline 2009 & 30628394 & 2426362 & 5 & 1 & 4.6 & 16.88 \\
\hline 2010 & 48465492 & 5083126 & 4 & 1 & 6.5 & 28.5 \\
\hline 2011 & 55333467 & 4815421 & 5 & 1 & 6.50 & 24.70 \\
\hline 2012 & 66330229 & 5120287 & 5 & 1 & 6.4 & 24.7 \\
\hline 2013 & 82700556 & 4156343 & 5 & 1 & 7.2 & 20.8 \\
\hline 2014 & 94127124 & 4389098 & 4 & 2 & 7.3 & 19.40 \\
\hline 2015 & 103403934 & 4408916 & 5 & 2 & 7.22 & 18.90 \\
\hline 2016 & 116515801 & 4670048 & 6 & 2 & 7.2 & 18.9 \\
\hline 2017 & 119191539 & 5078514 & 5 & 1 & 7.2 & 18.9 \\
\hline
\end{tabular}

(Source: Author Compilation based on the Statistics of Ministry of Tourism Government of India)

Table no. 1 gives details about the Foreign and Domestic Tourist arrivals statistics to Maharashtra State from the year 2001 to 2017. From the table it can be observed that, there was a slow increase in the number of domestic tourists visiting to the Maharashtra from 2001 to 2017. The rank of state in domestic tourist arrival has not improved significantly over the years, it ranges from 4 to 7 . Share percentage of domestic tourist has not crossed the $7.2 \%$. For the foreign tourist arrival state ranks top in the list in most of the years but the reason behind it is the Mumbai act as an entry and exist point for the foreign tourists.

(Pike, 2002) has found that, limited researchers have attempted to measure the destination image related to tourism attractions. Mostly these studies were conducted in by the developed regions of the world. Very few studies were conducted in India related to destination image. (Billimoria, 2015) has observed that, the because of recent competition in the tourism industry there is need of robust and assertive steps for the Marketing and branding of Maharashtra Tourism for changing its present image, status and position in tourism industry. Hence this study is a sincere attempt towards Destination Brand Image evaluation of Maharashtra Tourism from the perspectives of domestic and foreign tourists visiting to the cultural attractions of Maharashtra.

The objective of the study:

To assess the difference between experience and expectations of domestic and foreign tourists regarding the brand image of Maharashtra tourism. (perception of brand image)

\section{Hypothesis:}

1. $\mathrm{H}_{0} 1$ - There is no significant difference between experience and expectations of domestic and foreign tourists regarding brand image of Maharashtra tourism.

2. $\mathrm{H}_{0} 1.1$ - There is no significant difference between experience and expectations of domestic tourists regarding brand image of Maharashtra tourism.

3. $\mathrm{H}_{0} 1.2$ - There is no significant difference between experience and expectations of foreign tourists regarding brand image of Maharashtra tourism.

\section{Research Methodology:- Sampling:}

For collecting the domestic and foreign tourist's data from sample destinations Aurangabd, Nasik, Pune, Nagpur, Mumbai, Ratnagiri and Amravati were selected where Maharshtra Tourism Development Corporation (MTDC) has its regional offices by using purposive sampling. Survey was conducted at cultural heritage attractions like caves, 
monuments, historical buildings, art galleries and museums for 435 domestic and 663 foreign tourists at the sample destinations with the help of structured questionnaire.

\section{Research Instrument:}

The structured questionnaire was used as a research instrument for conducting the survey. Initial part of the questionnaire consists of the demographic profile of the respondent which consists of age, gender and educational qualification, state/country of Residence and length of stay in Maharashtra. Second part consists of questions related to expectations before coming Maharashtra and experiences of tourist after visiting Maharashtra. Various attributes were rated on 5-point Likert scale from strongly disagree to strongly agree.

For analyzing and processing the data SPSS (Software Package for Social Sciences) was used. Paired sample t-test was used for testing the hypothesis.

\section{Findings:}

Demographic profile of the respondents

Table 2:- Demographic profile of the respondents.

\begin{tabular}{|c|c|c|c|c|}
\hline & \multicolumn{2}{|c|}{ Domestic Tourists } & \multicolumn{2}{|c|}{ Foreign Tourists } \\
\hline & Frequency & Percent & Frequency & Percent \\
\hline \multicolumn{5}{|l|}{ Age } \\
\hline $18-30$ & 101 & 23.2 & 96 & 14.5 \\
\hline $31-40$ & 132 & 30.3 & 164 & 24.7 \\
\hline $41-50$ & 111 & 25.5 & 212 & 32.0 \\
\hline $51-60$ & 71 & 16.3 & 145 & 21.9 \\
\hline above 60 & 20 & 4.6 & 46 & 6.9 \\
\hline \multicolumn{5}{|l|}{ Gender } \\
\hline Male & 255 & 58.6 & 417 & 62.9 \\
\hline Female & 180 & 41.4 & 246 & 37.1 \\
\hline \multicolumn{5}{|c|}{ Educational Qualification } \\
\hline SSC & 52 & 12.0 & 29 & 4.4 \\
\hline HSC & 116 & 26.7 & 76 & 11.5 \\
\hline Graduation & 138 & 31.7 & 287 & 43.3 \\
\hline Post-Graduation & 129 & 29.7 & 271 & 40.9 \\
\hline \multicolumn{5}{|l|}{ Length of Stay } \\
\hline 1 to 3 days & 100 & 23.0 & 209 & 31.5 \\
\hline 3 to 5 days & 152 & 34.9 & 239 & 36.0 \\
\hline 5 to 7 days & 99 & 22.7 & 180 & 27.1 \\
\hline More than 7 days & 84 & 19.3 & 35 & 5.3 \\
\hline
\end{tabular}

Descriptive statistics was used for analyzing the demographic profile of the respondents. Results of the analysis are indicated in table no.2. The domestic tourists were in the rage of 31-40 years (30\%), followed by range of 41-50 years $(25.5 \%)$ and foreign tourists 'were $41-50$ years (32\%) next is 31-40 years (24.7\%). Domestic tourists' gender is considered male are $58.6 \%$ and female are $41.4 \%$ and foreign tourist male $62.9 \%$ and females $37.1 \%$. Domestic tourists educational qualification is considered $31.7 \%$ respondents are graduates and $29.7 \%$ are post graduates, similarly for foreign tourist $43.3 \%$ are graduates and $40.9 \%$ are post graduates. Analysis of length of stay of domestic tourist is considered $34.9 \%$ respondents stayed for 3 to 5 days and $23 \%$ for 1 to 3 days. For foreign tourists $36 \%$ respondents stayed for 3 to 5 days and $31.5 \%$ for 1 to 3 days. According to (Ministry of Tourism Government of India, 2018) average duration of stay by foreign tourist is 21 days but findings of this study shows that, length of stay of foreign tourist in Maharashtra is very low than the national average.

\section{Hypothesis Testing:}

1. $\mathrm{H}_{0} 1$ - There is no significant difference between experience and expectations of domestic and foreign tourists regarding brand image of Maharashtra tourism.

2. $\mathrm{H}_{0} 1.1$ - There is no significant difference between experience and expectations of domestic tourists regarding brand image of Maharashtra tourism. 
3. $\mathrm{H}_{0} 1.2-$ There is no significant difference between experience and expectations of foreign tourists regarding brand image of Maharashtra tourism.

Table No 3:- Paired sample t test.

\begin{tabular}{|c|c|c|c|c|c|c|c|}
\hline & Destination Attributes & \multicolumn{3}{|c|}{ Domestic Tourists } & \multicolumn{3}{|c|}{ Foreign Tourists } \\
\hline & & $\mathrm{t}$ & $\mathrm{df}$ & $\begin{array}{l}\text { Sig. } \\
\text { (2-tailed) }\end{array}$ & $\mathrm{t}$ & $\mathrm{df}$ & $\begin{array}{l}\text { Sig. } \\
\text { (2-tailed) }\end{array}$ \\
\hline Pair 1 & Maharashtra has many well-known tourist sites & 3.518 & 434 & .000 & 10.608 & 662 & .000 \\
\hline Pair 2 & The destination is rich in cultural heritage & 3.229 & 434 & .001 & 5.445 & 662 & .000 \\
\hline Pair 3 & Destination has good accessibility & 10.798 & 434 & .000 & 6.212 & 662 & .000 \\
\hline Pair 4 & $\begin{array}{l}\text { The environment at the destination is very clean } \\
\text { and maintained }\end{array}$ & 4.672 & 434 & .000 & 15.496 & 662 & .000 \\
\hline Pair 5 & $\begin{array}{l}\text { Destination has good infrastructure and } \\
\text { facilities }\end{array}$ & 5.077 & 434 & .000 & 10.676 & 662 & .000 \\
\hline Pair 6 & $\begin{array}{l}\text { Destination has qualified, helpful and friendly } \\
\text { service staff and guides }\end{array}$ & 7.305 & 434 & .000 & 17.037 & 662 & .000 \\
\hline Pair 7 & $\begin{array}{l}\text { Destination is safe and secure place for } \\
\text { travelers }\end{array}$ & 4.985 & 434 & .000 & 18.638 & 662 & .000 \\
\hline Pair 8 & Destination is value for money destination & 8.247 & 434 & .000 & 15.599 & 662 & .000 \\
\hline
\end{tabular}

For testing both the sub hypothesis $\mathrm{H}_{0} 1.1$ and $\mathrm{H}_{0} 1.2$ paired sample $\mathrm{t}$ test was used. The paired sample $\mathrm{t}$-test is a statistical technique used to determine whether the mean difference between two sets of observations is zero. In a paired sample t-test, each subject or entity is measured twice. In this study domestic and foreign tourist are measured two times for expectations and experiences. The table no. 3 showed that, level of significance is less than 0.05 for $t$ value of all the destination attributes at 95\% confidence interval hence we rejected the null hypothesis and accepted the alternate hypothesis that 'There is significant difference between experience and expectations of domestic tourists regarding brand image of Maharashtra tourism' and 'there is significant difference between experience and expectations of foreign tourists regarding brand image of Maharashtra tourism.'

Difference between the Experience and the Expectations of the destination attributes.

A result of hypothesis testing clearly indicates that there is statistical significant difference between experience and expectations of domestic and foreign tourists regarding brand image of Maharashtra tourism. This gap between domestic and foreign tourist's expectation and experiences is shown in the table no.4.

Table No 4:- Differences between the Experience and the Expectations of the destination attributes.

\begin{tabular}{|c|c|c|c|c|c|c|c|}
\hline & 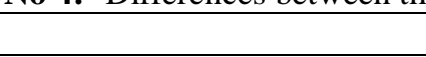 & \multicolumn{3}{|c|}{ Domestic Tourist } & \multicolumn{3}{|c|}{ Foreign Tourist } \\
\hline $\begin{array}{l}\text { Sr. } \\
\text { No. }\end{array}$ & Destination attributes & $\begin{array}{l}\text { Mean- } \\
\text { Experience }\end{array}$ & $\begin{array}{l}\text { Mean- } \\
\text { Expectation }\end{array}$ & Gap & $\begin{array}{l}\text { Mean- } \\
\text { Experience }\end{array}$ & $\begin{array}{l}\text { Mean- } \\
\text { Expectation }\end{array}$ & Gap \\
\hline 1 & $\begin{array}{l}\text { Maharashtra has many well- } \\
\text { known tourist sites }\end{array}$ & 3.24 & 3.44 & -0.2 & 3.04 & \begin{tabular}{|l}
3.53 \\
\end{tabular} & -0.49 \\
\hline 2 & $\begin{array}{l}\text { The destination is rich in } \\
\text { cultural heritage }\end{array}$ & 3.26 & 3.43 & -0.17 & 3.41 & 3.66 & -0.25 \\
\hline 3 & $\begin{array}{lll}\begin{array}{l}\text { Destination } \\
\text { accessibility }\end{array} & \text { has good } \\
\end{array}$ & 3.22 & 3.88 & -0.66 & 2.98 & 3.30 & -0.32 \\
\hline 4 & $\begin{array}{l}\text { The environment at the } \\
\text { destination is very clean and } \\
\text { maintained }\end{array}$ & 3.10 & 3.41 & -0.41 & 2.89 & 3.65 & -0.82 \\
\hline 5 & $\begin{array}{l}\text { Destination has good } \\
\text { infrastructure and facilities }\end{array}$ & 3.17 & 3.50 & -0.33 & 3.00 & 3.48 & -0.48 \\
\hline 6 & $\begin{array}{l}\text { Destination has qualified, } \\
\text { helpful and friendly service } \\
\text { staff and guides }\end{array}$ & 3.12 & 3.56 & -0.44 & 2.88 & 3.71 & -0.83 \\
\hline 7 & $\begin{array}{l}\text { Destination is safe and } \\
\text { secure place for travelers }\end{array}$ & 3.28 & 3.55 & -0.27 & 2.96 & 3.82 & -0.86 \\
\hline
\end{tabular}




\begin{tabular}{|l|l|l|l|l|l|l|l|}
\hline 8 & $\begin{array}{l}\text { Destination is value for } \\
\text { money destination }\end{array}$ & 3.06 & 3.60 & -0.54 & 2.77 & 3.56 & -0.79 \\
\hline
\end{tabular}

Results of the study indicates that, highest gap between for experience and expectation for domestic tourist's is for the destination attribute 'Destination has good accessibility' (-0.66), followed by 'Destination is value for money destination' (-0.54), and 'Destination has qualified, helpful and friendly service staff and guides' (-0.44). Least difference is for the attributes 'The destination is rich in cultural heritage' (-0.17) and 'Maharashtra has many wellknown tourist sites' $(-0.2)$

For the foreign tourists highest gap is for the attributes 'Destination is safe and secure place for travelers' (-0.86), next is 'Destination has qualified, helpful and friendly service staff and guides' $(-0.83)$ and 'the environment at the destination is very clean and maintained' (-0.82). Minimum difference is for the attribute 'The destination is rich in cultural heritage' (-0.25) subsequently 'Destination has good accessibility' $(-0.32)$ and 'Destination has good infrastructure and facilities' (-0.48).

\section{Conclusions:-}

Findings of the study indicates that there is difference between expectations and experiences of the domestic as well as foreign tourists regarding destination attributes of brand image of Maharashtra. Highest gap for domestic tourists for the destination attribute 'Destination has good accessibility' $(-0.66)$, shows that there is need of improvement in accessibility which is core segment of tourism industry. Better accessibility by rail, road, sea and air to the important tourist attractions in Maharashtra is essential for smooth and comfortable journey of tourists which will help in creating strong brand image to attract more tourists. Higher gap for 'Destination is value for money destination' (0.54) reflects that, Maharashtra Tourism is falling short on most beneficial combination of cost, quality and sustainability to meet domestic tourist's requirements. There is scope for improvement in quality of tourism services and visitor experiences. High gap for 'Destination has qualified, helpful and friendly service staff and guides' (0.44 ), indicates that, there is lack of trained and qualified staff in tourism industry to cater professional services to the tourists. Maharashtra Tourism should take initiative for creating and recruiting qualified tourism professionals in industry which will help brand enhancement. Lowest difference for the 'The destination is rich in cultural heritage' $(-0.17)$ shows that, Maharashtra Tourism brand image is based on the varied and rich cultural heritage it has like caves, monuments, historical buildings, art galleries, museums etc. Lower value for 'Maharashtra has many wellknown tourist sites' (-0.2) indicates that, domestic tourists are well versed with the important tourist attractions of the Maharashtra.

For the foreign tourists highest gap is for the attributes 'Destination is safe and secure place for travelers' $(-0.86)$, which reflects that, foreign tourists does not consider Maharashtra as safe and secure destination to travel. Few timely initiatives by Maharashtra Police like 'Tourism Police' at least at important tourist places like world heritage sites and Archaeological Survey of India (ASI) ticketed monuments may help to change this perception of foreign tourists.

Higher gap for 'Destination has qualified, helpful and friendly service staff and guides' (-0.83) also indicate the lack of qualified and trained staff at hotels, travel agencies, government organization, airlines and tour guiding offering services to the foreign tourists. High gap for 'the environment at the destination is very clean and maintained' (0.82 ), shows that, foreign tourist are not satisfied with the cleanliness and maintenance of tourist attractions in Maharashtra which could be the major hurdle in creating strong brand image of the Maharashtra Tourism. Initiatives like 'Swaccha Bharat, Swaccha Paryatan' (clean India, clean tourism) by Ministry of Tourism Government of India will help to create awareness among the tourism stakeholders for cleanliness of tourist destinations.

Lowest difference for 'The destination is rich in cultural heritage' $(-0.25)$ shows that, even foreign tourists agree that Maharashtra has a rich cultural heritage. Lower difference for attribute 'Destination has good accessibility' (-0.32), indicates that some important tourist attractions visited by foreign tourist like Ajanta, Ellora, Chhatrapati Shivaji Maharaj Terminus (CST) has good connectivity by rail, road, and air. 


\section{Suggestions:-}

1. There is need of improve the accessibility to important tourists' attractions like ticketed monuments by ASI and other important tourist attractions sites by rail, road, sea and air to for creating better brand image of Maharashtra.

2. Government of Maharashtra should take initiative for creating, recruiting and retaining the trained and qualified staff for offering better tourism services and service encounter to tourists.

3. Brand image of Maharashtra should reflect the rich cultural heritage like caves, monuments, historical buildings, art galleries, museums etc.

4. Maharashtra Police should start 'Tourism Police' wing at least at important tourist places like world heritage sites and Archaeological Survey of India (ASI) ticketed monuments for creating a sense of safety and security among domestic and foreign tourists based on the model of Rajasthan Police.

5. MTDC can implement aggressively 'Swacch Bharat, Swaccha Paryatan' campaign at important tourist places for creating awareness among tourist and tourism stakeholders regarding cleanliness of monuments.

6. For increasing length of stay of foreign tourist in Maharashtra variety of tourism products can be introduced which includes culture, wildlife, cuisine, adventure sports etc. at least to achieve the national average 21 days.

7. MTDC should use cultural festivals like Ajanta Ellora festival, Elephanta festival, Kalaghoda festival and other events strategically for creating a positive brand image of Maharashtra Tourism.

\section{References:-}

1. Ashton, A. S. (2014). Tourist destination brand image development — an analysis based on stakeholders perception: A case study from Southland, New Zealand. Journal of Vacation Marketing, 20(3), $279-292$. https://doi.org/10.1177/1356766713518061

2. Billimoria, R. (2015). Marketing Strategies for the Tourism Development in Maharashtra (SNDT Women's University Mumbai). Retrieved from https://shodhganga.inflibnet.ac.in/handle/10603/88633

3. D'Silva, B., \& D'Silva, S. (2008). Perception of tourists towards India as a Preferred Tourist Destination - An Empirical Research. Conference on Tourismin India-Challenges Ahead, 159-164. Retrieved from http://citeseerx.ist.psu.edu/viewdoc/download?doi=10.1.1.629.7325\&rep=rep1\&type=pdf

4. Department of Tourism \& Culture Affairs Government of Maharashtra. (2016). Maharashtra Tourism Policy 2016 (p. 6). p. 6. Retrieved from http://www.indiaenvironmentportal.org.in/files/file/mtdc-tourism-policy2016.pdf

5. Ekinci, Y. (2003). From Destination Image to Destination Branding : An Emerging Area of Reserach. E-Review of Tourism Reserach (eRTR), 1(2), 21-24. Retrieved from https://agrilifecdn.tamu.edu/ertr/files/2012/09/138_c-1-2-1.pdf

6. Hanzaee, K. H., \& Saeedi, H. (2011). A Model of Destination Branding For Isfahan City: Integrating the Concepts of the Branding and Destination Image. Interdisciplinary Journal of Reserach in Business, 1(4), 1228. Retrieved from https://pdfs.semanticscholar.org/3535/fa4cb934c0cd9ca0a5848e19ac3d3aaab01c.pdf

7. Hunter, W. C. (2012). Projected Destination Image : A Visual Analysis of Seoul. Tourism Geographies: An International Journal of Tourism Space, Place and Environment, 14(3), 419-443. https://doi.org/DOI: 10.1080/14616688.2011.613407

8. Kim, S., \& Yoon, Y. (2003). The Hierarchical Effects of Affective and Cognitive Components on Tourism Destination Image. Journal of Travel \& Tourism, 14(2), 1-22. https://doi.org/10.1300/J073v14n02

9. Li, X., \& Vogelsong, H. (2002). A Model of Destination Image Promotion with a Case Study of Nanjiang, P.R. China. Proceedings of the Northeastern Recreation Research Symposium, (1993). Retrieved from https://www.nrs.fs.fed.us/pubs/gtr/gtr_ne302/gtr_ne302_194.pdf

10. Maharashtra Tourism Development Corporation. (2015). Tourism Survey for the State of Maharashtra April 2014 to March 2015. Retrieved from http://tourism.gov.in/sites/default/files/Other/Maharashtra_0.pdf

11. Maharshtra Tourism Development Corporation. (n.d.). Experiential Tourism. Retrieved from Maharshtra Tourism Development Corporation website: https://www.maharashtratourism.gov.in/mahabhraman/index

12. Maumbe, K. (2015). Destination brand Cape Town \& Western Cape : an assessment of consumer-based brand equity ( $\mathrm{CBBE}$ ). African Journal of Hospitality, Tourism and Leisure, 4(2), 1-20. Retrieved from http://www.ajhtl.com/uploads/7/1/6/3/7163688/article6vol4(2)2015_july-nov.pdf

13. Meža, P., \& Seric, N. (2014). Destination Branding through the Perception of the Tourists : Case from Croatia. Human Capital without Borders: Managment, Knowledge and Learning Quality of Life Knowledge and Learning, 77-87. Retrieved from http://www.toknowpress.net/ISBN/978-961-6914-09-3/papers/ML14-479.pdf 
14. Ministry of Tourism Government of India. (2018). India Tourism Statistics 2018. Retrieved from http://tourism.gov.in/sites/default/files/Other/India Tourism Statistics 2018.pdf

15. Naidoo, P., Ramseook-munhurrun, P., \& Durbarry, R. (2010). Tourists' perspective of the brand image of mauritius. International Journal of Marketing Reserach, 3(3), 95-106. Retrieved from https://papers.ssrn.com/sol3/papers.cfm?abstract_id=1880309

16. Pike, S. (2002). Destination image analysis - a review of 142 papers from 1973 to 2000. Tourism Managment, 23, 541-549. from http://citeseerx.ist.psu.edu/viewdoc/download?doi=10.1.1.201.7956\&rep=rep1\&type=pdf

17. Piva, E., Cerutti, S., Prats, L., \& Raj, R. (2017). Enhancing Brand Image through Events and Cultural Festivals : the Perspective of the Stresa Festival' s Visitors. Almatourism Journal of Tourism, Culture and Territorial Development, 15, 99-116. https://doi.org/https://doi.org/10.6092/issn.2036-5195/6888

18. Qu, H., Hyunjung, L., \& Hyunjung, H. (2011). A model of destination branding : Integrating the concepts of the branding and destination image. Tourism Management, 32(3), 465-476. https://doi.org/10.1016/j.tourman.2010.03.014

19. Varghese, N. (2002). Maharashtra shows its wares. The Hindu Business Line. Retrieved from https://www.thehindubusinessline.com/catalyst/2002/08/22/stories/2002082200070300.htm

20. Verissimo, J., Tiago, M., Tiago, F., \& Jardim, J. (2017). Tourism destination brand dimensions : an exploratory approach Tourism destinatio. Tourism and Management Studies, 13(4), 1-8. https://doi.org/10.18089/tms.2017.13

21. Vora, D. (2012). Maharashtra , unplugged. Mid-Day.com, pp. 1-10. Retrieved from https://www.midday.com/articles/maharashtra-unplugged/161672

22. We are Progresssively Becoming an Ideal Tourist Destination. (2016). Indian Business Journal, (September), 34-35. Retrieved from http://online.fliphtml5.com/gmzl/fpaw/\#p=34

23. World Travel \& Tourism Council. (2019). Travel \& Tourism Economic Impact 2019 World. Retrieved from https://www.wttc.org/-/media/files/reports/economic-impact-research/regions-2019/world2019.pdf

24. Xesfingi, S., Papadopoulou, G., Karamanis, D., \& Martens, H. M. (2018). Visitors' satisfaction in Dubai and pre-trip pre-trip destination image (No. 89850). Retrieved from https://mpra.ub.uni-muenchen.de/89850/. 